\title{
Reaching Out from a Small Scientific Community: The Social Influence Models of Collaboration across National and Disciplinary Boundaries for Scientists in Three Fields of Social Sciences
}

\author{
Srebrenka LETINA \\ Institute for Social Research in Zagreb, Croatia \\ srebrenka@idi.hr (corresponding author) \\ Garry ROBINS \\ Melbourne School of Psychological Sciences, University of Melbourne, Australia \\ garrylr@unimelb.edu.au \\ Darja MASLIĆ SERŠIĆ \\ Department of Psychology, Faculty of Humanities and Social Sciences, University of \\ Zagreb, Croatia \\ darja.maslic@ffzg.hr
}

\begin{abstract}
Collaboration among scientists from different fields or countries is important for scientific progress in general, particularly for scientists working in small peripheral scientific communities. The aim of this study was to investigate the network effects in three disciplinary scientific communities in social sciences in Croatia on the probability of scientists to establish co-authorship/collaboration outside the community. Co-authorship data from publications indexed in two international databases (Web of Science and Scopus) and one national database (National and University Library) were used to define the networks. Autologistic actor attribute models enabled the testing of three network effects (Activity, Contagion and Popularity /Ego-2Star/) while controlling for six actor attributes. The results confirmed the hypotheses about positive Contagion (the probability of establishing outside collaborations is higher if immediate network partners have also been collaborating outside the field) and negative Activity (scientists collaborating with one or more scientists outside the national and disciplinary community are less active in that network) for educational sciences, provided mixed support in the case of sociology (only negative Activity was confirmed), while the field of psychology showed no network effects. A significant effect was observed for the number of co-authored papers whereas the scientist's age and number of single-authored papers were not significant in any of the three disciplines, Gender, location and maximum strength of a tie proved to be of different importance for different fields. Methodological issues in co-authorship network analysis are discussed and directions for future research are proposed.
\end{abstract}

Key words: autologistic actor attribute models (ALAAM), co-authorship network, scientific collaboration, national and disciplinary community (NDC), peripheral scientific community, social sciences 


\section{Introduction}

Collaboration among scientists is often presumed to be linked with higher productivity and quality of scientific outputs. Although some authors have questioned the positive association (e.g. Toomela, 2007; Duque et al., 2005; Lee and Bozeman, 2005), in most literature collaboration is considered to be important for scientific progress in general and for the career development of individual scientists. This view is often reflected in research-funding policies where collaboration is seen as having inherent value. A long list has been proposed, enumerating possible motives, functions and consequent benefits of collaboration for both the individual scientist (Beaver, 2001; Bozeman and Corley, 2004; Fox and Faver, 1984), and for scientific progress in general. In the contexts where different types of expertise and experience are required to address a research problem adequately, collaboration may increase the likelihood of novelty and reduce the chance of fundamental errors, particularly interdisciplinary or international collaboration (Beaver, 2004). Accordingly, collaboration in general - often measured by the share of multi-authored papers or by the average number of authors per paper - has been on the rise in the majority of scientific disciplines (Wuchty, Jones and Uzzi, 2007). This is especially valid for international and interdisciplinary collaboration (Glänzel and Schubert, 2005; Etzkowitz and Leydesdorff, 2001).

Since the mid-1990s, there has been a burst of studies of collaboration using social network approaches, frequently relying on co-authorship data, from different disciplinary and theoretical perspectives. Most of these studies looked at general network properties (Moody, 2004; Newman 2001, 2004), dealing, implicitly or explicitly, with collaboration within the disciplines (e.g. Bellotti, 2012; De Stefano et al., 2011). These studies often leave aside actor attributes or collaborations outside the discipline, not only because of a lack of the theoretical perspective, but also because of a lack of data or appropriate statistical methods to examine attributes and collaborative ties simultaneously. Some research on individual and institutional predictors of external collaborations has focussed only on international (Melkers and Kiopa, 2010) or interdisciplinary collaborations (Woolley, Sánchez Barrioluengo and Turpin, 2012; Van Rijnsoever and Hessels, 2011), but it is mostly directed towards central scientific communities (e.g. USA and Western Europe) in the fields of hard sciences (e.g. physics and biomedicine). 
In this study we focussed on external collaboration in general - collaboration taking place when a scientist crosses disciplinary or/and national borders. We defined external collaboration as any co-authorship with a scientist belonging to a different national or disciplinary community. In contrast to most network studies of collaboration, those using a whole network design based on bibliometric data, we aimed to predict the probability of external collaboration by an individual actor, taking into account the internal network structure of the actor's community, and at the same time, some socio-demographic attributes available through additional data sources. Methodologically, we accounted for the network structure of the intradisciplinary and national community as well as for actor attributes in predicting external collaboration by employing auto-logistic actor attribute model (ALAAM) - a recently developed extension of exponential random graph models (ERGM) permitting a prediction of attribute outcomes based on network structure (Daraganova and Robins, 2013).

In this paper we are using three dimensions (discipline, national context and associated core-periphery position) to describe three scientific networks in Croatia. Specifically, we regard scientists active in one of three fields of social sciences (psychology, sociology, educational sciences) as three separate networks occupying a similar position in the global scientific community due to the same location operationalized through a shared national context. This context implies a shared linguistic, geographical, historical and cultural background. While those scientists are similar in respect of their location and core-periphery position, they are seen here as three distinct networks because of their differing disciplinary backgrounds. Our focus in this research is on boundary-crossing out of the national and/or disciplinary community (NDC). A co-authorship with anyone outside the "internal" network defined by the discipline and national context represents an external collaboration. Those external ties do not necessarily need to be directed toward a more central part of the global science network (for example, collaboration with a scientist from another country also located at the periphery), they are nevertheless connections outside the home community.

This paper is structured as follows; in the next two sections we describe our general theoretical framework of external collaboration in a small and peripheral scientific community, proceeding to the introduction to ALAAMs. Subsequently we present our research hypotheses and de- 
scribe the data and the analyses. Following the results presentation and interpretation, we finalise the paper with a general discussion and concluding remarks.

\subsection{Theoretical framework}

Even if all scientists were part of one global scientific network, science would not operate as a single community consisting of hundreds of thousands of individual scientists. Instead, that large community is sub-divided into various networks with identifiable, although porous, disciplinary and national boundaries (Mali et al., 2012). The global structure is thus organised around disciplinary imperatives, where geographical location often determines denser national clusters of highly interconnected scientists, while the connections with other clusters are more sparse. Co-authorship networks in science have a "modular structure" (Lambiotte and Panzarasa 2009: 181). Besides its modularity, the global scientific network has a core-periphery structure (Schott, 1998). In such a structure, some countries and their scientific communities play a leading role, becoming the centres of knowledge production (e.g. Schott et al., 1998; Meadows, 1997; Wagner, 2008). Most research and scientific outputs, such as publications, are produced in these central scientific communities. Nevertheless, there is a growing body of literature recognising the importance of location and focussing on the difference between the sites of knowledge production and the ways in which knowledge is both produced and received (Rodriguez Medina, 2014: 10).

We draw on the ecological model from the community of psychology as a useful and appropriate theoretical framework to understand a national and disciplinary scientific community. "Community suggests the idea of persons coming together in some shared endeavour or at least geographic proximity: e.g. groups, neighbourhoods and larger structures“ (Dalton, Elias and Wandersman, 2007: 15). Thus, a community is defined broadly, considering that an individual lives in many communities, often at multiple levels, existing within the global context. The community exists at different ecological levels of analysis. These levels are classified according to their distance from the individual: the most proximal systems that are closest to the individual are nested within broader, more distant systems, less immediate to the person but having broad effects. The boundaries between each system are porous, allowing the extension of relationships across different 
systems. Thus, our approach uses the ecological models to describe the social environments of scientists and their impact on him/her. It is appropriate because it is based on the interdependence between a person and the context in which $\mathrm{s} / \mathrm{he}$ is embedded.

\subsection{Disciplinary communities on the scientific periphery}

Based on his study of social scientists (in the field of political science) in Argentina, Rodriguez Medina (2014) recognised a distinction between the central and peripheral communities, describing their different scientific practices. ${ }^{1}$ On the one hand, central communities are highly institutionalised, have strong universities, government agencies, powerful publishing houses, professional associations, extended networks, and so on. Crucially, sources of capital, as well as material and symbolic resources are local. In those centres, social sciences usually have a high level of autonomy. On the other hand, peripheral communities typically have a smaller number of members and are rarely specialised (since the job market and consumers of knowledge do not require them to be). Science is developed mainly in the university system, mostly at public institutions. Sources of capital are mainly found in more developed parts of the world and more advanced scientific communities. The autonomy is low due to the influence of the economy or politics on the standards of scientific production, and due to the absence of long-term policies and strong institutions. Besides the national context, an important shaping force of individual academics is provided by the disciplines. Their influence can be understood as cultural, as they provide membership in a group with distinct traditions, languages, accepted modes of conduct, definitions of knowledge, modes of research, the style of working and collaborating with others, and the approach to publishing (Lewis, 2013).

Crossing interdisciplinary and international boundaries could be particularly important for scientific progress in small and peripheral scientific communities. It prevents a community from being isolated and parochial, enabling participation in the global scientific community, as well as achievement of recognition and scientific excellence. Additionally, the rewards for an individual scientist may be substantial. However, the tendency

1 "[...] since science is situated and happens in certain spaces, social worlds where science takes place are one of the symbolic and material constraints for scientific practice." (Rodriguez Medina, 2014: 14) 
to have collaborators from the same discipline and location (homophily and proximity) is well-known and could be a major mechanism contributing to the so-called small-world structure of scientific networks (Perc, 2010; Watts and Strogatz, 1998). On the other side, an important commonality of all types of external ties (interdisciplinary, international and intersectional) is that they are more time-consuming and demanding for the individual. While external ties do offer potential for career development, they also entail relatively riskier endeavours.

Constraints typical for the peripheral communities (small membership, lack of resources, lack of specialisation, etc.) make reaching out important for the visibility and ultimate success in the recognition of a scientist. Moreover, researchers from the periphery are not only motivated because of a self-interest to widen their networks of collaborators, but are also often pressured by the national science policy, and the criteria for research funding and evaluation, all of which can favour interdisciplinary and international collaboration. The outcome of outside collaborations is more likely to be published in journals with a wider and international audience, making it more likely to be cited (Abramo, D'Angelo and Solazzi, 2011; Andrade, López and Martín, 2009; Sonnenwald, 2007). ${ }^{2}$ These external ties could be beneficial for a small peripheral community in its efforts to build up to a scale required to make a serious international impact.

\subsection{Methodological framework for studying the influence of internal collaborations on external collaboration}

Most studies of co-authorship networks and the main models of collaboration network structure have been criticised for ignoring the actor attributes and treating all the nodes as equal. Previous research on international or interdisciplinary collaboration has pointed to certain individual and institutional factors as important predictors of productivity in science (Woolley, Sánchez Barrioluengo and Turpin, 2012; Melkers and Kiopa, 2010). We are proposing models that include both network effects and actor attribute

\footnotetext{
${ }^{2}$ Of course it is possible to collaborate internally and publish in international and/or multidisciplinary journals (with those papers written mostly in English) as well as to collaborate externally but publish the output of that collaboration in domestic journals (dominantly in Croatian language in this context). Even though it is reasonable to assume that these patterns of collaboration and publishing are less likely, there is no perfect correlation between the kinds of collaboration, internationality and multidisciplinarity of journals where outputs are published, and the language used.
} 
effects simultaneously. This is in line with the current network research, which is moving away from simple descriptions towards statistical modelling (for a review, see Kolaczyk, 2009), allowing inferences about the structure of an empirical social network. Since well-formulated network statistical models do not assume that individuals are independent of one another so standard statistical methods, such as logistic or multiple regression, are inappropriate. We assume that observations (individual attributes) may be dependent upon each other through network connections (Kashima et al., 2013).

To predict a scientist's engagement in external collaboration based on the internal collaboration network, we used autologistic actor attributes models. ALAAM is a variant of the well-established exponential random graph model of social network structure, and is one of the social influence models in network analysis. ${ }^{3}$ Whereas an ERGM predicts the presence of network ties based on attributes, an ALAAM predicts individuallevel attributes from network ties. It enables a construction of ERGM-like models for the patterns of social influence within a network (Robins, Pattison and Elliott, 2001). In contrast to ERGMs, where we model ties and focus on network structure, ALAAM is used to model an attribute of interest (dependent stochastic variable) according to the ties (independent fixed variable measured on the dyadic level) and other attributes (other independent variables measured on the individual level). An ALAAM can be compared to a logistic regression, but one that takes into account network dependencies. In ALAAM, those dependencies arise from the network ties, which are collaborations within the NDC in the context of this research, and are treated as exogenous or explanatory. Dependence assumptions in an ALAAM rest on the basic idea that the probability of an attribute being present depends not only on other individual factors (as in a standard logistic regression) but also on the presence of the attribute in the network neighbourhood of the actor. In that sense, individuals may influence one another through the network. However, ALAAM is not without its limitations: it is not suited for very large networks, it does not take into account the strength of ties and it is a cross-sectional network model that deals with a binary attribute, although it can be extended to valued relations (Daraganova and Robins, 2013: 113). An advantage of

\footnotetext{
${ }^{3}$ More about social influence models in network analysis can be found in the works of Friedkin and Johnsen (1990, 1997), Valente (1995), Friedkin (1998), and An (2011).
} 
ALAAM is its "considerable flexibility in formulating models to examine different types of dependencies among variables" (Daraganova and Robins, 2013: 103). In addition, it "allows examination of a wider range of possibly important interactions" (Robins, Pattison and Elliott, 2001). As with ERGMs in general, different configurations representing different social processes can be tested, enabling a multi-theoretical and eclectic approach.

The site of our research was social scientific collaboration in Croatia. Scientists active in one of the following fields were considered in this research: psychology, sociology and educational sciences. The choice of scientific fields in this study was informed by the formal classification system of science in Croatia at the time of data collection. ${ }^{4}$ Croatia has a formal register of scientists, where scientists are classified into a single field of research, the discipline in which they earned their most recent degree. The crossing from one discipline to another, although not impossible, is rare in Croatia. Therefore, the categorisation of researchers based on the field is highly likely to reflect their on-going field of research. In order to be promoted, each scientist must meet the requirements which are slightly different for every field and are liable to regular revision. Three social science fields investigated in this study are similar in regard to their least publishable unit, speed and frequency of publishing and length of publications. Therefore, they are not unsuitable for comparison.

\section{Research hypotheses}

According to the general hypothesis of our study, the ties an individual has (or has not) established in the home community, and the tendency of his/her network partners to collaborate with someone outside their community, influence his/her probability of doing the same. In other words, our general hypothesis was that reaching outside one's own community is network-dependent.

That general hypothesis was elaborated through two specific research hypotheses:

\footnotetext{
${ }^{4}$ The field of educational sciences is composed of several different disciplines: pedagogy, sports science and education and rehabilitation sciences. It represents a heterogeneous field resulting from a specific classification system of social sciences in Croatia. More recently, since the data collection, this field has undergone a major reclassification and has been broken down into a few distinct disciplines. In this article we retain the original umbrella description of educational sciences.
} 
H1: Scientists collaborating with one or more scientists outside the $N D C$ are less active in the NDC network (Activity effect). Social scientists at the periphery are "not in the same boat" with the scientists from more central communities or from hard science disciplines, and one way to achieve recognition is to collaborate with them. Furthermore, engagement in interdisciplinary or international collaboration could set them apart from their original community and has its risks. A recent longitudinal study of the entire Slovenian scientific community (Ferligoj et al., 2015), which used the stochastic-actor-based models, found that - for social sciences and the humanities - collaboration with other researchers outside the NDC had a negative effect on the formation of ties with scientists within the NDC. However, authors also found that publication excellence measured through impact factors of journals in which a scientist has published had a positive effect. On the other hand, outside collaboration had a positive effect on tie formation for scientists from other scientific areas (biotechnical, medical, engineering and natural sciences). Thus, having collaborators outside the NDC could be related to less activity inside the NDC. Several possible mechanisms may be at work. Collaboration with others and especially with others outside one's NDC is time-consuming on the part of the individual scientist, which results in having less time available for other collaborators. Engaging in an outside collaboration, the individual (intentionally or not) "removes" himself or herself from his/her NDC, therefore having fewer opportunities to collaborate within the NDC.

H2: The probability of establishing outside collaborations is higher if immediate network partners have also been collaborating with persons outside the field (Contagion effect). Collaboration with peers within the NDC engaging in outside collaborations may lead to social influence effects. Researchers collaborating with peers engaging in outside collaborations may be introduced to outside collaborations through their partners, or may be encouraged themselves to seek outside collaborations, supported by experience, attitudes and information provided by their collaborators. Specifically, if a scientist had co-authored a paper with a peer from the NDC who has co-authors outside the NDC, social influence may occur due to the following: the scientist has access to outside collaborations through his/her collaborators within the NDC (and through their outside collaborators); therefore, his/her collabora- 
tors within the NDC engaging in outside collaborations may serve as models for normative behaviour in the discipline. These influences can be seen as two types of social influence described in social psychology as informational influence and normative influence (Deutsch and Gerard, 1955), respectively.

\section{Methodology}

\subsection{Study sample}

Data collection occurred in 2013 and included several stages: data retrieval, data cleansing, merging of different datasets and formatting network data. We began with the list of names of all scientists active in three fields of social sciences in Croatia according to the formal register of scientists of 2008 provided by the Ministry of Science, Education and Sports. The initial list included a total of 918 scientists, of which 481 educational scientists, 241 psychologists and 196 sociologists.

\subsection{Data collection}

We used the names from the formal register, along with a defined time period of interest (1992-2012) ${ }^{5}$ as the parameters of queries in three different databases. The databases used included two international databases: Web of Science (WoS; Thomson Reuters) and Scopus (Elsevier). For the purpose of better coverage, we also used one national database: online library catalogue of the National and University Library (Nacionalna i sveucilišna knjižnica; NSK). From the international databases we extracted all indexed papers of each person listed, published in the 1992-2012 period. From the NSK we extracted only monographs, books and reports over 30 pages long. Those publications are associated with more rigorous peer review, stronger visibility and relatively larger weight in the evaluation process (of an individual or a project) than short reports and articles published in domestic journals not covered by prestigious databases. Therefore, the resulting network can be viewed as comprising stronger collaborative ties. A detailed account of the extraction process and final dataset of publications are provided in Letina (2016).

Following the data cleansing we merged the data extracted from the three databases into one original database. In total, $31 \%$ of publications were extracted from the NSK, and the remaining $69 \%$ from WoS or Scopus.

\footnotetext{
51992 was the year of diplomatic recognition of Croatia as an independent state while 2012 was the year preceding the data collection.
} 
Table 1. Description of the publications dataset

\begin{tabular}{lcccc}
\hline Field & Psy & Soc & Edu & Total \\
\hline No of publications & 1833 & 1334 & 1818 & 4769 \\
\hline No of all different co-authors of publications & 2947 & 894 & 1894 & 5006 \\
\hline No of authors from the initial sample & 218 & 170 & 371 & 759 \\
(\% of all co-authors) & $(7.4)$ & $(19)$ & $(19.6)$ & $(15.2)$ \\
\hline No of co-authors not from the initial sample & 2729 & 724 & 1523 & 4247 \\
\hline No (\%) of single-authored papers & 407 & 797 & 557 & 1761 \\
\hline No (\%) of co-authored papers & $(22.2)$ & $(59.7)$ & $(30.6)$ & $(36.9)$ \\
\hline No of papers with two co-authors & 1426 & 537 & 1261 & 3008 \\
\hline No of papers with three co-authors & $(77.8)$ & $(40.3)$ & $(69.4)$ & $(63.1)$ \\
\hline No of papers with 4 to 10 co-authors & 494 & 245 & 437 & 1111 \\
\hline No of papers with more than 10 co-authors & 723 & 168 & 483 & 995 \\
\hline Mean (Mdn) of all co-authors per paper & $4.14(3)$ & $1.99(1)$ & $2.77(2)$ & $2.99(2)$ \\
\hline
\end{tabular}

No - number; Mdn - median; Psy - Psychology; Soc - Sociology; Edu - Educational Sciences.

As can be seen from Table 1, only a small proportion of all co-authors of publications extracted for each field were included in the initial list. This clearly shows that the scientists from the list had collaborated with many others not listed as working scientists in their discipline or country. Additionally, not all scientists had publications in the 21-year time period listed in the three databases. In total, 759 of 918 had at least one publication.

\subsection{Network data}

From the original database, we constructed a network of collaboration for each of the three disciplines. The formal register of scientists in Croatia defined the network boundary for the disciplines of our interest. The networks included every scientist from the register who had published at least one publication in the last 21 years. We excluded non-academic researchers from this sample. ${ }^{6}$ Therefore, final networks include 160 nodes in psychology, 136 in sociology and 250 in educational sciences (Table 2).

\footnotetext{
${ }^{6}$ We excluded all actors-scientists who were not working in the academic context (university or research institute), as our focus was on academic research and publishing. Publishing activities, and therefore co-authorship patterns, have higher and different significance
} 
Table 2. Description of the final sample

\begin{tabular}{|c|c|c|c|c|c|c|}
\hline Field & Gender & Frequency & $\%$ & Location & Frequency & $\%$ \\
\hline \multicolumn{7}{|c|}{ Psychology $(N=160)$} \\
\hline & Male & 41 & 25.6 & In Zagreb & 101 & 63.1 \\
\hline & Female & 119 & 74.4 & Outside Zagreb & 59 & 36.9 \\
\hline \multicolumn{7}{|c|}{ Sociology $(N=136)$} \\
\hline & Male & 71 & 52.2 & In Zagreb & 109 & 80.1 \\
\hline & Female & 65 & 47.8 & Outside Zagreb & 27 & 19.9 \\
\hline \multicolumn{7}{|c|}{ Educational sciences $(N=250)$} \\
\hline & Male & 108 & 43.2 & In Zagreb & 160 & 64 \\
\hline & Female & 142 & 56.8 & Outside Zagreb & 90 & 36 \\
\hline
\end{tabular}

We assumed the relationship in co-authorship is symmetrical. Thus, the ties in the network were treated as undirected. We also did not consider the strength of ties, using a binary measure of collaboration where 1 means two actors co-authored one or more papers, and 0 means two actors did not coauthor any paper. From the database, we also extracted the information on the number of external collaborations of the researchers in each network, which was treated as nodal attribute data in this study. Accordingly, we defined the dependent variable and predictors, as described in the sections below.

\subsection{Analytical strategy: Autologistic actor attribute models}

In our analysis we used a class of cross-sectional network models to understand how the behaviour (nodal attribute) of individual scientists - in this study, those reaching outside one's own NDC - may be associated with the position in a social network of the NDC and with the behaviour of other actors (scientists) in the network. Network effects were specified through configurations included in our models (presented in Table 3). Effect names and notation used in Table 3 were drawn from Daraganova and Robins (2013).

for the scientists employed at universities and research institutes than for scientists employed at other types of institution (e.g. hospitals, schools). 
Table 3. Structural effects (parameters) included in ALAAM in Model 1 and Model 2

\begin{tabular}{|c|c|c|}
\hline EFFECT & CONFIGURATION & EXPLANATION \\
\hline $\begin{array}{l}\text { Attribute density } \\
\text { Model } 2\end{array}$ & & Number of nodes with attribute $Y$ \\
\hline Activity & & $\begin{array}{l}\text { Is an ego with attribute } \mathrm{Y} \text { more } \\
\text { likely to have ties with others in } \\
\text { the network? }\end{array}$ \\
\hline Contagion & & $\begin{array}{l}\text { What is the propensity of each } \\
\text { pair of nodes in the network to } \\
\text { have attribute Y? }\end{array}$ \\
\hline $\begin{array}{l}\text { Ego-2Star } \\
\text { Popularity }\end{array}$ & & $\begin{array}{l}\text { Is an ego with an attribute more } \\
\text { popular in the network? }\end{array}$ \\
\hline $\begin{array}{l}\text { Alter-2Star1 } \\
\text { Mixed collaborators } \\
\text { Not included in the } \\
\text { model but included in the } \\
\text { goodness-of-fit }\end{array}$ & & $\begin{array}{l}\text { Is an ego connected with an alter } \\
\text { without or with attribute } \mathrm{Y} \text {, and } \\
\text { connected with an alter having } \\
\text { attribute } \mathrm{Y} \text {, more or less likely to } \\
\text { have that attribute? }\end{array}$ \\
\hline $\begin{array}{l}\text { Alter-2Star2 } \\
\text { High numbers of external } \\
\text { collaborators } \\
\text { Not included in the } \\
\text { model but included in the } \\
\text { goodness-of-fit }\end{array}$ & & $\begin{array}{l}\text { Is an ego with ties with two } \\
\text { alters, both having attribute Y, } \\
\text { more or less likely to have that } \\
\text { attribute? }\end{array}$ \\
\hline $\begin{array}{c}\text { T1 } \\
\text { Attribute in closed structures } \\
\text { Not included in the } \\
\text { model but included in the } \\
\text { goodness-of-fit }\end{array}$ & & $\begin{array}{l}\text { Is an ego with two connected } \\
\text { alters without attribute } \mathrm{Y} \text {, more or } \\
\text { less likely to have that attribute? }\end{array}$ \\
\hline $\begin{array}{c}\text { T2 } \\
\text { Attribute in closed structures } \\
\text { with mixed partners } \\
\text { Not included in the } \\
\text { model but included in the } \\
\text { goodness-of-fit }\end{array}$ & & $\begin{array}{l}\text { Is an ego with two connected } \\
\text { alters, one of which is having } \\
\text { attribute } Y \text {, more or less likely to } \\
\text { have that attribute? }\end{array}$ \\
\hline $\begin{array}{c}\text { T3 } \\
\text { Attribute in closed structures } \\
\text { with attributed partners } \\
\text { Not included in the } \\
\text { model but included in the } \\
\text { goodness-of-fit }\end{array}$ & & $\begin{array}{l}\text { Is an ego with two connected } \\
\text { alters with attribute Y, more or } \\
\text { less likely to have that attribute? }\end{array}$ \\
\hline
\end{tabular}

Node filled with diagonals - ego for which the probability of having the attribute is predicted. White node - alter with or without the attribute.

Black node - alter with the attribute. 
In our ALAAM models, the attribute of interest - engagement in one or more collaborations outside the NDC - was taken as a binary stochastic variable measured at the individual level of actors in the network. The network ties within the NDC were regarded as an independent fixed variable measured at the dyadic level. The basic assumption of the model was that the probability of the presence of an attribute of interest depends on the presence of the attributes in the local network neighbourhoods of actors, or/and on the position of actors in the network, or/and on other attributes of the actor.

A probability of observing the binary attribute $Y$ for each possible observation in the network $\mathrm{X}$ is expressed as follows (Daraganova and Robins, 2013: 104):

$$
\operatorname{Pr}(Y=y \mid X=x)=\frac{1}{\kappa\left(\theta_{I}\right)} \exp \left\{\sum_{I} \theta_{I} z_{I}(y, x)\right\}
$$

Where $\theta_{I}$ and $z_{I}$ are parameters and statistics for network-attribute configurations involving an interaction of the dependent variable (y) and network variable $(\mathrm{x}) ; \kappa\left(\theta_{I}\right)$ is a normalising quantity ensuring the probability sums up to 1 ; and $\mathrm{y}$ and $\mathrm{x}$ represent the observed values of the attribute and network variables (both are binary). Since $Y$ is a binary variable, if there are no network effects, the model is reduced to a logistic regression (Daraganova and Robins, 2013: 105). However, taking the network $X$ into account enables a proper modelling of the dependence among observations of the attribute $Y$ induced by the network. In particular, we can parameterise the patterns of ties and attributes presented in Table 3 .

The equation presented above describes the probability distribution of attributes on the $N$ nodes of a given graph $x$. Based on the frequency of various configurations and on parameter values, a specific probability is assigned to every possible vector of attributes. The aim of this model is to describe the distribution of attributes across the network and identify tie configurations that are more likely to be relevant while taking into consideration other actor-level attributes (Kashima et al., 2013).

The dependent variable $Y$ refers to the presence or absence of collaboration outside the NDC. The initial models included all the parameters presented in Table 3, and six actor attributes. Although not hypothesised, for the sake of completeness we have included the Popularity effect (Ego- 
2Star) in our models. This parameter tested the generalised influence hypothesis about how a certain network position was related to the outcome of interest. Due to model overfitting and insignificant effects, the final models were more parsimonious with a smaller number of parameters, based on the backward selection approach. To avoid model overfitting, we decided to fix the density effect in the models. Before entering the variables in the ALAAM analysis, we centred all the continuous variables to minimise multicollinearity.

\subsection{Dependent variable}

The dependent variable in this study (Collaboration outside NDC) was the number of all co-authors that were not part of the academic field in Croatia, that is, for each actor in the field it was the number of unique names of co-authors that were not part of the NDC according to the formal register of scientists in the field.

\subsection{Predictors}

\subsubsection{Collaboration within the national and disciplinary community}

Collaboration within the NDC was expressed as the number of all co-authors in the network of the academic field in Croatia, that is, all registered scientists in the field, working in the academia and with at least one publication in the investigated time period. The specified effects are explained in section 3.4.

\subsubsection{Actor attributes}

One of the advantages of using the ALAAM approach for predicting the outcome of interest is the possibility of including additional actor attributes in the model. Although the primary aim of this study was to investigate network effects on the probability of external NDC collaboration, we also considered some potentially relevant actor attributes as control variables.

In total, six actor attributes were included in the model as controls. Three variables were based on the information from the national register of scientists: 1) gender (0: male; 1: female); 2) age in 2012; 3) location categorised as working in the capital city of Zagreb or in other parts of Croatia (0: outside Zagreb; 1: Zagreb). Additionally, two variables were extracted from the original dataset of publications. The total number of publications 
for each scientist was separated in two variables: 4) number of co-authored papers of each actor; 5) number of single-authored papers. Finally, one actor attribute was derived from the weighted co-authorship network: 6) maximum strength of ties (MST) was the number of co-authorships with the most frequent collaborator, regardless of his/her discipline or country. For instance, if a scientist from the sample authored three papers, I, II and III, where paper I was co-authored with scientists A and B; paper II was co-authored with B and C; while paper III had no co-authors, the maximum strength of ties for that scientist would be two (collaborations with B). We included this variable in order to consider some information about the strength of ties between actors. When considered together with the number of papers published, the MST measured the actor's propensity to engage in collaborations with a single, specific, long-term research partner. As with our dependent variable, that variable could be regarded as a special type of actor attribute, since both were derived from the characteristics of the actor's ties.

The model fitting was performed using MPNet software for ERGMs (Wang et al., 2014). The visualisation and analysis of network data was performed using UCINET VI (Borgatti, Everett and Freeman, 2002).

\section{Results}

\subsection{Univariate and bivariate statistics}

Descriptive statistics relating to scientists who do and do not collaborate externally as well as correlations of continuous variables included in the attribute effects model and the dependent variable before dichotomisation for each field of science are presented in Table 4. In all variables except Age, highly positively skewed distributions and major differences between the mean and the median reflect the presence of outliers. In all three fields, the majority of scientists collaborated outside their NCD, but $13-28 \%$ had only internal collaborations. 


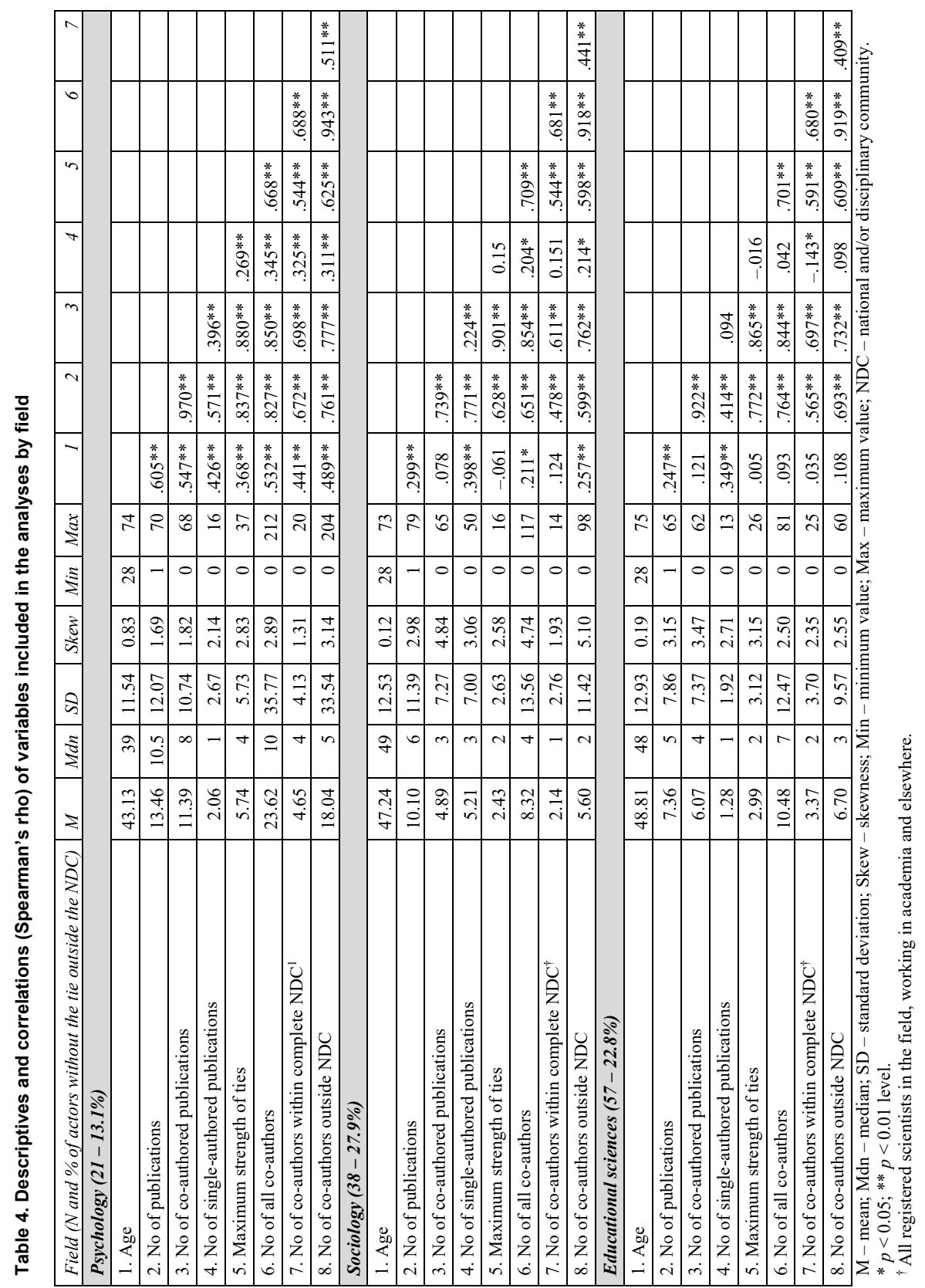




\subsection{Description of co-authorship networks}

In Table 5, we present network descriptives for the three disciplines.

Table 5. Network descriptives for three fields

\begin{tabular}{|c|c|c|c|}
\hline Variable & Psychology & Sociology & $\begin{array}{l}\text { Educational } \\
\text { sciences }\end{array}$ \\
\hline Number of nodes & 160 & 136 & 250 \\
\hline Number of ties & 334 & 132 & 740 \\
\hline Density & 0.026 & 0.014 & 0.012 \\
\hline Average degree & 4.175 & 1.941 & 2.96 \\
\hline Degree centralisation & 0.075 & 0.083 & 0.081 \\
\hline Average distance & 4.014 & 4.107 & 4.724 \\
\hline Diameter & 9 & 10 & 11 \\
\hline Transitivity (triad) & 0.127 & 0.223 & 0.124 \\
\hline Clustering coefficient & 0.491 & 0.591 & 0.507 \\
\hline Components & 17 & 60 & 68 \\
\hline Isolates & 11 & 20 & 20 \\
\hline Isolated dyads & 2 & 7 & 11 \\
\hline Isolated triangles & 0 & 1 & 1 \\
\hline$\overline{\mathrm{E}-\mathrm{I}}$ index ${ }^{\dagger}$ & 0.225 & 0.250 & 0.138 \\
\hline
\end{tabular}

* Overall, unweighted.

$\dagger$ Average E-I index of all nodes, where the number of internal ties included all internal collaborators, even those scientists who were from the same field and country, but wee not working in the academia.

The transitivity and clustering coefficient, which indicated the tendency of a pair of co-authors to have the same third co-author, was the highest among sociologists. In contrast, the sociology network had the highest percentage of isolates (members of a network who co-authored no papers with any other scientists in their NDC), $14.7 \%$, while in psychology and educational sciences the percentage was considerably lower, $6.8 \%$ and $8 \%$, respectively. The number of all components was also relatively higher in the networks of sociology and educational sciences than in the psychology network, suggesting a greater fragmentation and lower connectedness in those fields.

Co-authorship network visualisations are shown in Figures 1, 2 and 3. The network of psychologists was more interconnected and the density was the highest in comparison to the other two networks. A visual inspection 
of the graphs shows one important and distinct feature of the educational sciences network compared to the other two. The main component in the field has two clusters of actors connected via only one node. It reflects the heterogeneity of this field that actually includes three separate subfields. The smaller cluster (upper right in Figure 3) mostly consists of scientists from the education and rehabilitation subfield, while the larger and more connected cluster (lower right in Figure 3.) mostly includes sports scientists. Other components mostly, but not exclusively, comprise scientists from the field of pedagogy. The sociology field had a relatively high share of actors with no external ties, but the E-I index (Table 5) was the highest for sociologists. That suggests sociologists were relatively more inclined to have external collaborators when compared with the number of their internal collaborators.

Figure 1. Visualisation of the co-authorship network of psychologists

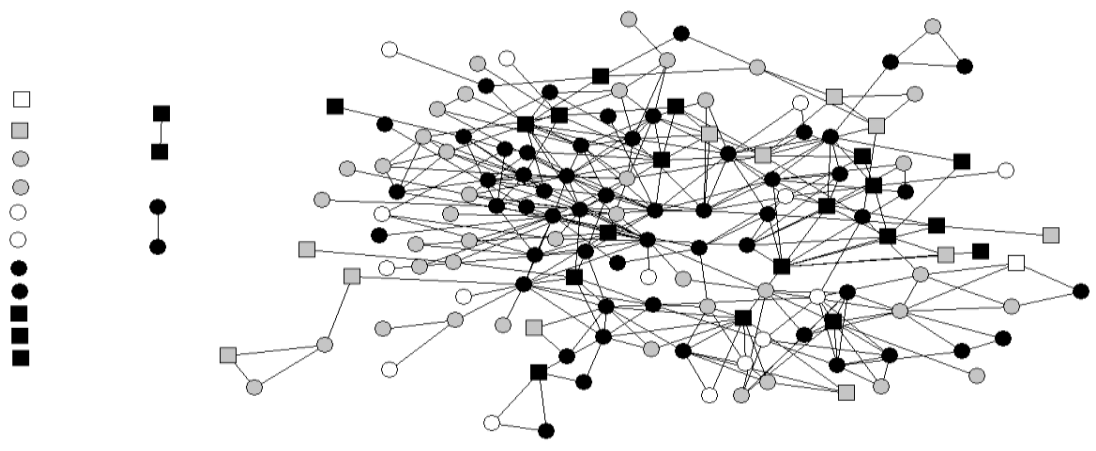

Figure 2. Visualisation of the co-authorship network of sociologists

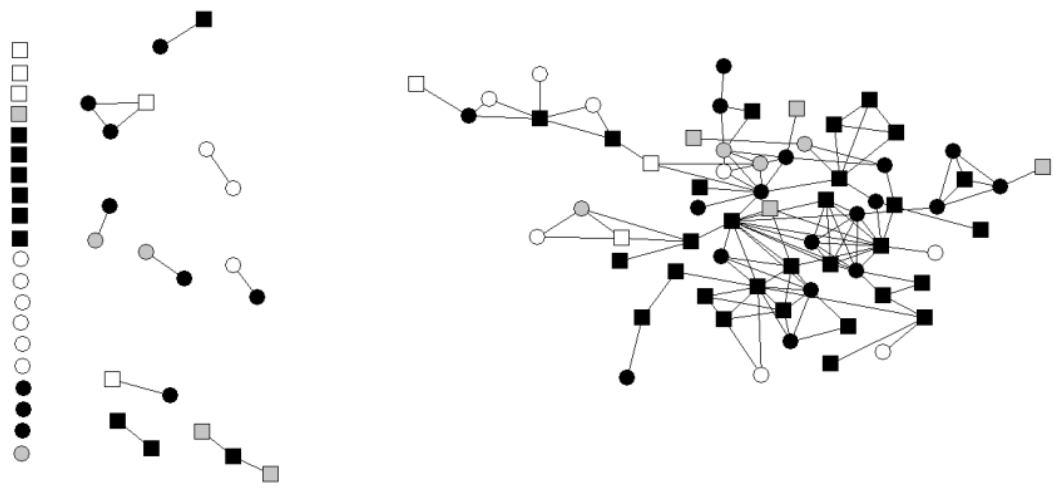


Figure 3. Visualisation of the co-authorship network of educational scientists

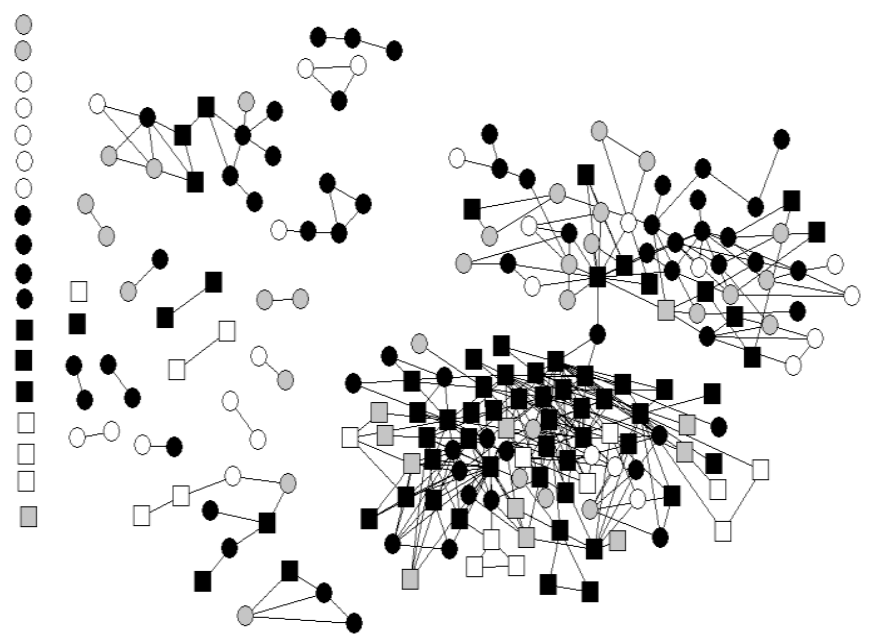

Shape of nodes:

Circle $=$ female

Square $=$ male

Colour of nodes:

White $=$ without external collaborators

Grey $=$ one to median number of collaborators

Black $=$ median or larger number of collaborators

\subsection{Results of the auto-logistic actor attribute models}

To answer our main research questions, we fitted the models for each field network separately, with the same parameters for three network effects: Contagion, Activity and Ego-2star (Popularity). We controlled for six actor attribute effects - gender, location, age, maximum strength of ties (MST), number of co-authored papers and the number of single-authored papers as predictors of the propensity to collaborate.

Parameter estimates and approximate standard errors applying to the models are presented in Table 6. Parameter estimates converged for all the presented models. Goodness-of-fit (t-ratios) was lower than or close to the 0.1 value for all included effects, indicating an excellent or good fit. For parameters not included in both models (Table 7), t-ratios were below 2, suggesting adequate model specifications (Robins and Lusher, 2013). 
Table 6. ALAAM estimates for models by three fields

\begin{tabular}{|c|c|c|c|c|c|c|}
\hline \multirow{3}{*}{ Effects } & \multirow{2}{*}{\multicolumn{2}{|c|}{$\begin{array}{c}\text { Psychology } \\
\text { One or more ties } \\
\text { outside NDC }\end{array}$}} & \multicolumn{2}{|c|}{ Sociology } & \multicolumn{2}{|c|}{$\begin{array}{l}\text { Educational } \\
\text { sciences }\end{array}$} \\
\hline & & & \multicolumn{2}{|c|}{$\begin{array}{c}\text { One or more ties } \\
\text { outside NDC }\end{array}$} & \multicolumn{2}{|c|}{$\begin{array}{c}\text { One or more ties } \\
\text { outside NDC }\end{array}$} \\
\hline & Estimates & $S E$ & Estimates & $S E$ & Estimates & $S E$ \\
\hline \multicolumn{7}{|c|}{ Structural effects } \\
\hline Attribute - Density & Fixed & - & Fixed & - & Fixed & - \\
\hline Activity & 0.805 & 1.08 & -3.746 & $1.62 *$ & -2.664 & $0.53 *$ \\
\hline Contagion & -0.570 & 1.09 & 1.507 & 1.48 & 1.870 & $0.46 *$ \\
\hline Ego-2Star & -0.106 & 0.07 & 1.620 & $0.72 *$ & 0.207 & 0.19 \\
\hline \multicolumn{7}{|c|}{ Actor-attribute effects } \\
\hline Gender & -0.337 & 0.42 & 0.007 & 0.35 & -0.188 & 0.21 \\
\hline Location & 0.033 & 0.33 & -0.212 & 0.40 & 0.548 & $0.21 *$ \\
\hline Age & 0.009 & 0.02 & 0.006 & 0.01 & -0.007 & 0.01 \\
\hline $\begin{array}{l}\text { No of co-authored } \\
\text { papers }\end{array}$ & 0.196 & $0.10 *$ & 2.234 & $0.65 *$ & 0.924 & $0.19 *$ \\
\hline $\begin{array}{l}\text { No of single-authored } \\
\text { papers }\end{array}$ & -0.062 & 0.08 & 0.022 & 0.04 & -0.051 & 0.08 \\
\hline $\begin{array}{l}\text { Maximum strength } \\
\text { of ties }\end{array}$ & 0.022 & 0.14 & -1.628 & $0.64 *$ & -0.529 & $0.21 *$ \\
\hline
\end{tabular}

NDC - national and/or disciplinary community; Mdn - median; SE - standard error; No - number.

$* p<0.05$.

Table 7. Goodness-of-fit of ALAAM estimates for models by three fields

\begin{tabular}{lccccccccc}
\hline & \multicolumn{3}{c}{ Psychology } & \multicolumn{3}{c}{ Sociology } & \multicolumn{2}{c}{ Educational sciences } \\
\cline { 2 - 13 } & \multicolumn{2}{c}{ One or more ties outside } & One or more ties & outside & \multicolumn{2}{c}{ One or more ties outside } \\
& Observed & $M$ & t-ratio & Observed & $M$ & t-ratio & Observed & $M$ & t-ratio \\
\hline Parameter & 139 & 139 & - & 98 & 98 & - & 193 & 193 & - \\
\hline Density & 626 & 626.14 & -0.017 & 237 & 236.93 & 0.022 & 654 & 653.33 & 0.087 \\
\hline Activity & 293 & 293.12 & -0.015 & 107 & 106.90 & 0.031 & 299 & 298.21 & 0.123 \\
\hline Contagion & 1950 & 1950.25 & -0.007 & 531 & 530.89 & 0.029 & 2108 & 2105.97 & 0.151 \\
\hline Ego-2Star & 3811 & 3784.15 & 0.513 & 1003 & 1008.52 & -0.276 & 3958 & 3939.99 & 0.283 \\
\hline Alter-2Star1 & 1802 & 1775.20 & 0.542 & 466 & 469.26 & -0.169 & 1792 & 1782.64 & 0.161 \\
\hline Alter-2Star2 & 586 & 582.46 & 0.381 & 241 & 238.06 & 0.8 & 606 & 598.77 & 0.916 \\
\hline T1 & 563 & 554.51 & 0.478 & 231 & 225.46 & 0.789 & 575 & 562.39 & 0.931 \\
\hline T2 & 181 & 176.02 & 0.58 & 74 & 71.40 & 0.764 & 185 & 179.71 & 0.85 \\
\hline T3 & 512 & 512.03 & -0.01 & 121 & 121.08 & -0.026 & 312 & 312.08 & -0.016 \\
\hline Gender & 444 & 444.18 & -0.05 & -0.028 & -0.03 & -0.028 & 508 & 508.24 & -0.044 \\
\hline Location & & & & & & & &
\end{tabular}




\begin{tabular}{lccccccccc}
\hline Age & 111.52 & 106.86 & 0.06 & -28.08 & -28.39 & 0.004 & -1937.2 & -1926.14 & -0.08 \\
\hline $\begin{array}{l}\text { No of co-authored } \\
\text { papers }\end{array}$ & 4770.32 & 4770.52 & -0.009 & 1530.12 & 1529.94 & 0.026 & 5397.2 & 5395.89 & 0.085 \\
\hline $\begin{array}{l}\text { No of single-authored } \\
\text { papers }\end{array}$ & 630.84 & 630.39 & 0.031 & 862.84 & 861.39 & 0.054 & -239 & -238.06 & -0.058 \\
\hline MST & 1593.24 & 1593.66 & -0.036 & 338.52 & 338.46 & 0.009 & 1572.6 & 1571.28 & 0.118 \\
\hline
\end{tabular}

NDC - national and/or disciplinary community; Mdn - median; $\mathrm{M}$ - mean of simulated networks; No - number; T1, T2, T3 - parameters not included in both models, for description see Table 3; MST - maximum strength of ties Grey cells - estimates for the effects not included in the model and for one fixed effect (Density).

Firstly we present and discuss the results relating to the structural effects for each field separately. We then proceed to describe the results of actor attribute effects.

\subsubsection{Predicting having one or more collaborators outside one's field (NDC)}

\subsubsection{Structural effects}

Overall, in the field of psychology there seem to be no network effects on one's probability of having co-authored a paper with one or more collaborators outside the NDC. All structural parameters were statistically insignificant, which suggests a lack of evidence of association between reaching outside one's field and network.

In the network of sociologists there were two structural effects that seemed to be important factors determining the probability of having one or more collaborators outside the NDC. Negative and significant Activity parameters suggest that those who were less active in terms of internal collaborations were also more likely to have had one or more external collaborations. This finding agrees with our research hypothesis that collaborating outside one's small national and disciplinary network can be costly for an individual as it is associated with less internal activity. The simplest explanation would be that, investing the time in collaborators outside the NDC, the individual is left with less time and fewer opportunities to establish potential collaboration within the NDC.

The Contagion effect is not significant, implying that researchers were not directly influenced by a partner's external collaborations. However, the Ego-2Star parameter, representing the effect of a high number of (internal) collaborators, was significant and positive. It means that with more than one, and in particular with many ties within the NDC, the 
probability of crossing the NDC boundary was higher. This effect may reflect the popularity of a scientist with many external collaborations. The effect, however, should be viewed in the context of negative and significant Activity parameter. The effect of the Activity parameter increases linearly with the number of network partners, $d$, while the effect of the Ego-2star parameter increases with $d^{2}$ - more precisely, as $d(d-1) / 2$ (for details on the statistics used in the ALAAM configurations, see Daraganova and Robins, 2013: 94). Therefore, with one or two collaborators given the negative Activity parameter, a researcher's probability of external collaboration decreased; whereas with more than two partners, the probability increased, and dramatically so with a large number of partners (i.e. a large $d$ ).

In the network of educational scientists, as in the case of sociologists, the probability of collaborating outside the field seems to be network-dependent. Finding structural effects in this field is perhaps surprising, given that the disciplinary categorisation actually comprises several different subfields. Nevertheless, the negative and statistically significant Activity parameter shows that having a collaborator outside the NDC was related with being less active within one's own NDC. The interpretation is consistent with the one provided for the network of sociologists.

In the field of educational scientists, the Contagion effect was positive and significant, meaning that one was more likely to have a collaborator outside the NDC if the collaborators within the NDC also had outside collaborators. That is consistent with our research hypothesis (collaborating with a scientist who has co-authored papers with scientists outside the NDC encourages external collaboration).

\subsubsection{Actor attribute effects}

In psychology, only the number of co-authored papers was a significant predictor of external collaboration. It is not surprising that having more coauthored papers was related to a higher probability of engaging in external collaboration.

The same effect of the number of co-authored papers was observed in the sociologists' network. In addition, there was a negative and significant effect of the maximum strength of ties, suggesting that a repeated co-authorship with the same co-author made an actor less likely to reach outside the field for collaboration when the co-author is from the same 
community, or less likely to reach for other external collaborators when the co-author is not from the same community. Here it is worth noting a different conclusion this finding suggests when compared with the simple bivariate correlations between the maximum strength of ties established with the number of collaborators outside the NDC (Table 4). The correlation suggests that engaging in repeated collaborations with the same author was related to having more external collaborators. The ALAAM, in contrast, indicated that, when controlling for structural effects and some actor attributes, a different, more complex and nuanced picture emerges. A researcher collaborating with only one partner outside or within the NDC, will have fewer ties (less activity) in the network. When we control for activity in the model, we find a negative effect on the number of ties, suggesting that less activity will encourage more external collaboration. We now can see that the previously positive bivariate correlation masked the Activity effect, while the unique effect of the maximum tie strength was actually negative.

In the network of educational scientists, the statistically significant actor attributes the included number of co-authored papers and the maximum strength of a tie, similarly to the sociologists. According to our results, there was also a significant positive effect of the location. This suggests that being located in the capital city makes one more likely to establish external collaboration. It is not obvious why this effect was observed for educational sciences and not for the other two disciplines, but there is a cluster of scientists active in the subfield of sports science at Zagreb University. This subfield is characterised by a high number of co-authors per paper, especially in the field of bioscience, which may increase the propensity for external collaboration.

\section{Discussion}

We used the co-authorship network of scientists within a national and disciplinary community to predict external collaboration, controlling for some relevant actor attributes. The outcome of having co-authorship ties with at least one person outside the disciplinary and national field, while controlling actor attributes, was network-dependent for the network of sociologists and the network of educational scientists. However, it was networkindependent for psychologists. Overall, we obtained mixed support for our research hypotheses. The results showed the majority of scientists had col- 
laborated outside their NDC. Although there are no comparative studies of the prevalence of external collaboration at individual level, such collaboration could be more prevalent in the peripheral communities in comparison with more central ones. That may not be so only because collaboration is perceived as important and desirable by the scientists, but also because of the relatively smaller size of the NDC, which limits the number of potential collaborators.

There are major differences between the discipline areas (humanities, social sciences, natural sciences) in terms of collaborative practices and the reasons why people work together or alone (Lewis, Ross and Holden, 2012). Social sciences tend to occupy the middle ground between solo researchers (as in the majority of the humanities) and large teams (as in the majority of natural science fields). Additionally, it is recognised that there is considerable variation within the area. Moreover, even within the individual disciplines some diversity in collaboration patterns according to specific subdisciplines and research topics is expected. This does not mean that a typical mode of collaboration does not exist. Many factors are associated with the tendency of multi-co-authorship (e.g. high consensus field, urban fields, quantitative methodology, high publishing dynamics) and the question of how the internal structure of collaboration in the disciplines relates to the propensity to establish external collaboration remains open. Disciplines in which multi-co-authorship is a dominant pattern may be expected to be more open to external collaborations as well. In contrast, highly dense networks of co-authors within a discipline could be related to fewer links with external authors. Thus, the extrapolation from the internal to external collaboration is not straightforward, particularly in a non-central NDC.

When predicting the presence of external collaboration, we found some network effects relevant for the fields of sociology and educational sciences but not for psychology. It seems that the research content of this field offers scientists the opportunities to be involved in external collaboration regardless of the collaboration patterns of their internal co-authors. Research topics in this field are possibly more universal, less local, making the international collaborations more likely. Educational sciences demonstrated the hypothesised results. The largest cluster of sports scientists, characterised with relatively higher productivity and larger research teams, may have a particularly strong influence. 


\subsection{Interpretation of cross-sectional co-authorship network analysis}

Co-authorship as a measure of collaboration is far from perfect. It has validity issues and is only a partial indicator of collaboration, as it is well known in the literature (Laudel, 2002; Katz and Martin, 1997; Melin and Persson, 1996). Studies of collaboration based on publications are inherently selective as they exclude all less successful collaborations that did not result in any tangible product. Additionally, co-authorship data in the social network analysis poses specific methodological issues relating to the definition of network boundaries, which is dependent upon the sources and procedures used for data extraction (for review see De Stefano, Giordano and Vitale, 2011; De Stefano et al., 2013; Letina 2016). In light of these issues, we will discuss the interpretation of network effects (Contagion and Activity), proceeding to more general limitations of co-authorship data and their role in this research.

Co-authorship network is a one-mode network constructed from bipartite networks. It means that we are treating, for example, one author who wrote three different papers with three different co-authors outside the field the same as an author who wrote one paper with three co-authors outside the field. The Contagion effect could be the result of a joint collaboration between two or more scientists from the NDC and someone outside the field. This would imply that the tendency to establish external ties flows through the network in pairs or groups, suggesting a specific mechanism of contagion. Engaging in external collaborations in pairs or groups could be the result of the organisational aspects of research projects or a strategy of individual scientists to make outside collaboration less risky. Even though the presence of the Contagion effect indicates that co-authors are more likely to have external collaborators, we do not know if they are collaborating with the same or with different partners outside the NDC. Coauthorship with the same partners would suggest the sharing of the social capital and the existence of closeness as a self-organising principle, while co-authorship with different partners suggests a shared external orientation. These are different underlying mechanisms. Lastly, the interpretation of this effect is limited by the nature of our analysis. Being cross-sectional, it cannot distinguish the social influence from social selection. A way to disentangle these two processes is by using stochastic actor oriented models (Snijders, 2011) on longitudinal data that enables a co-evolution frame- 
work in which both the contagion and selection can be modelled. When interpreting the Activity effect, we cannot infer causality, i.e. whether external collaboration influences the activity within the field or whether the activity within the field influences the tendency to collaborate outside. For example, a scientist not having enough collaborators within his/her NDC could be more inclined to reach outside the community in the search of (a) potential collaborator(s). In addition, having more potential and desirable collaborators outside the NDC can result in having less time for internal collaborations.

Co-authorship studies usually overlook the fact that research content is a major organising factor within the disciplines. Some research issues may require external collaborators, especially in the peripheral NDCs. It is a difficult matter to study a specific research content, even at the level of the discipline, let alone at the level of specific research projects. However, the results across our three fields demonstrate that, while there may be some broad generalities, there may also be some specific effects arising from the content of the discipline or the level of a project. These effects may be associated with the way in which disciplines cooperate and structure themselves into a wider scientific field, thereby relating to the network structure of collaboration, as well as with the ways in which the network constrains or facilitates collaboration. These issues will likely play out in different ways for peripheral and central scientific communities. It is important for the peripheral NDCs to reach out in order to engage with current up-todate scientific endeavours and to establish reputational and hence funding resources. The ways in which an NDC network may facilitate external collaboration may be crucial in this regard.

\subsection{Limitations of the study}

The matter of setting network boundaries is problematic for social network studies in general, and particularly for studies of co-authorship networks, bearing important implications and limitations for our research. Formal registers of scientists are often used in co-authorship network studies (e.g. Kronegger, Ferligoj and Doreian, 2011; Kronegger, et al., 2012; De Stefano, et al., 2013) as they represent a convenient and mostly correct way of defining network boundaries. However, there are some caveats worth considering. Due to the possible inaccuracy of the formal register, some co-authors belonging to the NDC were not included (retired and inactive 
scientists, deceased scientists, former scientists who had left the academia, research assistants who entered the academic system after 2008 and students). Those scientists are not listed in the formal register of 2008, but they could have co-authored papers published from 1992 to 2012. Ideally, we should have had a list of registered scientists for each year of the investigated time frame, but that data was unavailable. The repercussion of this lack of information is a possibility that some internal ties were wrongly attributed as external. This could bring about an overestimation of external collaborators. Additionally, our study suffers from a limitation typical for co-authorship studies - the incompleteness of publication data. We did not include all types of publications (e.g. conference proceedings, book chapters), publications not indexed in the international databases (WoS and Scopus) and in one national source (National and University Library). However, by using selected publications that are important in the formal assessment of individual scientists, and that are, on average, the result of a longer time and greater effort investment (because of a stricter peer review, among other factors), we were able to focus on possibly stronger and more relevant connections. This reduced "the noise" that would occur in the case of including all types of publications. Furthermore, we have not distinguished among different kinds of outside ties. Treating every outside tie as equal, we did not take into account a real possibility that some kinds of external collaboration are more prestigious and more valued and featured with different underlying mechanisms. Future research should look at different kinds of external ties more closely. The issue of time frame, which is also important, was not taken into consideration in our study. The publication data used for the creation of co-authorship networks included all the publications indexed in the 21-year time period (1992-2012). We analysed data only with regard to the whole period, without making any distinction between the ties appearing earlier or later in the investigated time frame. That is, having included all the publications indexed in the selected time period, we did not use the information about the year of publication in our analyses. In doing so, we cannot make any inference relating to network dynamics nor did we seek to make directional or causal inferences. We were looking at the association between external collaboration and the aggregated internal network across the entire history of the NDC during the given time period. Therefore, although our models have external collaboration as an outcome variable, our cross-sectional results cannot determine 
whether the NDC structure affects the outcome or vice versa. In fact, our hypotheses reflected this duality, because $\mathrm{H1}$ is advanced as external collaboration affecting the NDC structure and H2, the opposite. Nevertheless, the dynamics may be important. Although publication activity increased in all the three fields in the 21 st century, more recently it has seen a drop (Letina, 2014), suggesting that temporal effects may arise from the causes shared by, but external to the three disciplines. In the 21 -year time period, many important changes in the science policy and other relevant exogenous factors (e.g. the war in the early 1990s, global economic crises, changes in data sources coverage) influenced the publishing activity and, possibly, coauthorship patterns. We assume those factors had influenced the scientists in the three fields similarly, making the comparisons across the disciplines valid. The analysis of the network dynamics and a more comprehensive appreciation of possible causal directions are beyond the scope of this initial paper and constitute a matter for future work. Finally, the strength of ties of the NDC network was not possible to analyse using ALAAM, and our interpretations of some effects and the importance of the MST parameter indicate it is an issue for future research.

\section{Concluding remarks}

The main contributions of this paper are as follows: the proposition of a theoretical framework for investigating external collaboration, investigation of peripheral scientific communities ("a small fish in the small pond"), a comparison across three fields of social sciences and one of the first applications of ALAAM in this domain (Letina, 2016). The focus of our interest was external collaboration seen differently than in many previous studies, where the outcome of interest was often a particular measure of scientific success such as productivity (e.g. Abbasi, Altmann and Liaquat, 2011). We have looked at co-authorship data from a different angle. While any given scientist does not have much direct control of the resources and features of his/her scientific community, s/he can have somewhat more agency in the choice of collaborators, at least in more mature career phases. A strategic choice of collaborators could make an important difference in his/her position and the position of his/her community in the long run. In the sociology of science, it has long been accepted that most scientists are below average in productivity due to typically positive skewness and a high variance of productivity distributions (Lotka's law; Lotka, 1926) and that the Mathew 
effect ("rich get richer"; Merton, 1968) describes the mechanism of scientific success and recognition. It provides a deterministic and, indeed, quite a gloomy perspective of the scientific contribution of most scientists, particularly those at the periphery. In line with the community approach, we are taking a more social action stance - focussing on external collaboration as one of the possible avenues for changing that kind of predicament.

Throughout the paper we emphasised the importance of reaching out, but internal collaboration is of no less relevance. In small peripheral communities in particular, if one does not want to move out from his/her NDC, it is essential to have a few strong internal ties to allow a transfer of knowledge acquired through the external ties, to create awareness among NDC members about the scientist's work and to share the acquired social capital. The ideal configuration may be the one including both local network and external links. Achieving this is a challenging task and having collaborators with that kind of collaboration pattern can help. Our results showed that the specific disciplinary context matters. We found positive Contagion and negative Activity in the field of educational sciences, negative Activity in the sociology field, while the field of psychology showed no network effects. These findings could suggest that achieving the "optimal" configuration is less constrained by the internal ties in psychology than in other two fields.

Every collaboration relies on interpersonal networks of different types. The ties may be instrumental or friendly, and either can be construed as causing the other (Lewis, Ross and Holden, 2012). The importance of interpersonal networks in the formation of concrete collaborations could be more pronounced in social sciences in the peripheral communities. Qualitative interviews with scientists in resource-constrained research institutions in the developing countries (Ynalvez and Shrum, 2011: 206) revealed that knowing someone very important and collaborating with a "stranger" someone who was not personally very well-known - was not considered desirable. Rodriguez Medina (2014) explained this outcome as resulting from a lack of stable scientific tradition. At the periphery, formal channels of communication may have less relevance, and scientists have to develop and rely upon novel strategies and trust. They may turn to other forms of support: family ties, political bonds, personal links, informal mechanisms and personal connections (Vessuri, 1997; Kreimer, 2000). In that kind of a context, collaborators and their attributes possibly have more influence. Thus, it is arguable that in peripheral communities, the effect of internal 
networks may even be stronger than in more central communities. Most collaboration studies ignore the scientist's national context (location). As Rodriguez Medina (2014) pointed out, studies of scientific networks are usually carried out in the context of universities and research centres located in the "metropolitan" centres and their findings may not necessarily be transferable to peripheral contexts. This results in a lack of research on non-central scientific communities and disciplines (Anderson and Adams, 2008). In this paper, by using additional sources of information to include some attributes, we have moved beyond a typical co-authorship network study. ALAAMs have been used in only a few studies on different research subjects (Kashima et al., 2013; Daraganova and Pattison, 2013), and in this paper we applied them to scientific networks. We believe ALAAM provides a methodological tool for the reconciliation of different approaches in the studies of scientists' behaviour, particularly the sociology of science and the psychology of science. The possibility of including other attributes of an actor, as well as the attributes of his/her alters in the model, makes this approach, in our opinion, not only more realistic, but also a useful analytical tool to model any behaviour for which it is plausible to believe that the individual matters just as much as his/her social context.

\section{Acknowledgements}

This work has been supported in part by the Croatian Science Foundation under the project IP-09-2014-9351 (principal investigator Maja Jokić). We thank Krešimir Zauder for the help provided during the preparation and formatting of the data for social network analysis. We are indebted to Colin Gallagher and David Rolls for their help and advice in the analysis procedure. We would like to express our gratitude to the Australian Government for enabling this collaboration through Endeavour Fellowships.

\section{REFERENCES}

Abbasi, Alireza, Altmann, Jörn and Hossain, Liaquat (2011). "Identifying the effects of co-authorship networks on the performance of scholars: A correlation and regression analysis of performance measures and social network analysis measures", Journal of Informetrics, 5 (4): 594-607. doi: 10.1016/j.joi.2011.05.007

Abramo, Giovanni, D’Angelo, Ciriaco Andrea and Solazzi, Marco (2011). "The relationship between scientists' research performance and the degree of internationalization of their research", Scientometrics, 86 (3): 629-643. doi: 10.1007/ s11192-010-0284-7 
An, Weihua E. (2011). "Models and Methods to Identify Peer Effects", in: John Scott and Peter J. Carrington (eds). The SAGE Handbook of Social Network Analysis. London: SAGE, pp. 514-532.

Anderson, Warwick and Adams, Vincanne (2008). "Pramoedya's chicken: Postcolonial studies of technoscience", in: Edward J. Hackett, Olga Amsterdamska, Michael E. Lynch and Judy Wajcman (eds). The New Handbook of Science and Technology Studies, Third Edition. Cambridge, MA: MIT Press, pp.181-204.

Andrade, Helga Bermeo, López, Ernesto de los Reyes and Martín, Tomas Bonavia (2009). "Dimensions of scientific collaboration and its contribution to the academic research groups' scientific quality", Research Evaluation, 18 (4): 301-311. doi: 10.3152/095820209X451041

Beaver, Donald D. (2001). "Reflections on Scientific Collaboration (and its Study): Past, Present, and Future", Scientometrics, 52 (3): 365-377. doi: 10.1023/A:1014254214337

Beaver, Donald D. (2004). "Does collaborative research have greater epistemic authority?", Scientometrics, 60 (3): 399-408. doi: 10.1023/B:SCIE.0000034382.85360.cd

Bellotti, Elisa (2012). "Getting funded. Multi-level network of physicists in Italy", Social Networks, 34 (2): 215-229. doi: 10.1016/j.socnet.2011.12.002

Borgatti, Stephen P., Everett, Martin G. and Freeman, Linton C. (2002). Ucinet 6 for Windows: Software for Social Network Analysis. Harvard: Analytic Technologies.

Bozeman, Barry and Corley, Elisabeth (2004). "Scientists' collaboration strategies: Implications for scientific and technical human capital", Research Policy, 33 (4): 599-616. doi: 10.1016/j.respol.2004.01.008

Dalton, James H., Elias, Maurice J. and Wandersman, Abraham (2007). Community psychology: Linking individuals and communities. Belmont: Thomson Wadsworth.

Daraganova, Galina and Pattison, Phillipa (2013). "Autologistic Actor Attribute Model Analysis of Unemployment: Dual Importance of Who You Know and Where You Live", in: Dean Lusher, Johan Koskinen and Garry Robins (eds). Exponential Random Graph Models for Social Networks: Theory, Methods, and Applications. Cambridge: Cambridge University Press, pp. 237-247. doi: 10.1017/CBO9780511894701

Daraganova, Galina and Robins, Garry (2013). "Autologistic Actor Attribute Model", in: Dean Lusher, Johan Koskinen and Garry Robins (eds). Exponential Random Graph Models for Social Networks: Theory, Methods, and Applications. Cambridge: Cambridge University Press, pp. 102-114. doi: 10.1017/ CBO9780511894701

De Stefano, Domenico, Fucella, Vittorio, Vitale, Maria Prosperina and Zaccarin, Susanna (2013). "The use of different data sources in the analysis of co-authorship networks and scientific performance", Social Networks, 35 (3): 370-381. doi: 10.1016/j.socnet.2013.04.004

De Stefano, Domenico, Giordano, Giuseppe and Vitale, Maria Prosperina (2011). "Issues in the analysis of co-authorship networks", Quality and Quantity, 45 (5): 1091-1107. doi: 10.1007/s11135-011-9493-2 
Deutsch, Morton and Gerard, Harold B. (1955). "A study of normative and informational social influences upon individual judgment", The Journal of Abnormal and Social Psychology, 51 (3): 629-636. doi: 10.1037/h0046408

Duque, Ricardo B., Ynalvez, Marcus, Sooryamoorthy, R., Mbatia, Paul, Dzorgbo, Dan-Bright S. and Shrum, Wesley (2005). "Collaboration Paradox: Scientific Productivity, the Internet, and Problems of Research in Developing Areas", Social Studies of Science, 35 (5): 755-785. doi: 10.1177/0306312705053048

Etzkowitz, Henry and Leydesdorff, Loet A. (2001). Universities and the Global Knowledge Economy: A Triple Helix of University-industry-government Relations. London: Pinter.

Ferligoj, Anuška, Kronegger, Luka, Mali, Franc, Snijders, Tom, A. B. and Doreian, Patrick (2015). "Scientific collaboration dynamics in a national scientific system", Scientometrics, 104 (3): 985-1012. doi: 10.1007/s11192-015-1585-7

Fox, Mary Frank and Faver, Catherine, A. (1984). "Independence and cooperation in research: The motivations and costs of collaboration", Journal of Higher Education, 55 (3): 347-359. doi: 10.2307/1981888

Friedkin, Noah E. (1998). A Structural Theory of Social Influence. Cambridge: Cambridge University Press. doi: 10.1017/CBO9780511527524

Friedkin, Noah E. and Johnsen, Eugene C. (1990). "Social influence and opinions", The Journal of Mathematical Sociology, 15 (3-4): 193-206. doi: 10.1080/0022250X.1990.9990069

Friedkin, Noah E. and Johnsen, Eugene C. (1997). "Social positions in influence networks", Social Networks, 19 (3): 209-222. doi: 10.1016/S03788733(96)00298-5

Glänzel, Wolfgang and Schubert, András (2005). "Analysing scientific networks through co-authorship", in: Henk F. Moed, Wolfgang Glänzel and Ulrich Schmoch (eds). Handbook of quantitative science and technology research. London: Kluwer Academic Publishers, pp. 257-276.

Kadushin, Charles (2012). Understanding Social Networks: Theories, Concepts, and Findings. New York: Oxford University Press.

Kashima, Yoshihisa, Wilson, Samuel, Lusher, Dean, Pearson, Leonie, J. and Pearson, Craig (2013). "The acquisition of perceived descriptive norms as social category learning in social networks", Social Networks, 35 (4): 711-719. doi: 10.1016/j.socnet.2013.06.002

Katz, J. Sylvan and Martin, Ben R. (1997). "What is research collaboration?", Research policy, 26 (1): 1-18. doi: 10.1016/S0048-7333(96)00917-1

Kolaczyk, Eric D. (2009). Statistical Analysis of Network Data: Methods and Models. New York: Springer. doi: 10.1007/978-0-387-88146-1

Kreimer, Pablo (2000). “Una modernidad periférica? La investigación científica entre el universalismo y el contexto", in: Marcelo Montserrat and Jens Anderman (eds). La ciencia en la Argentina entre siglos: textos, contextos e instituciones. Buenos Aires: Manantial, pp. 187-200.

Kronegger, Luka, Ferligoj, Anuška and Doreian, Patrick (2011). "On the dynamics of national scientific systems", Quality and Quantity, 45 (5): 989-1015. doi: $10.1007 / \mathrm{s} 11135-011-9484-3$ 
Kronegger, Luka, Mali, Franc, Ferligoj, Anuška and Doreian, Patrick (2012). "Collaboration structures in Slovenian scientific communities", Scientometrics, 90 (2): 631-647. doi: 10.1007/s11192-011-0493-8

Lambiotte, Renaud and Panzarasa, Pietro (2009). "Communities, knowledge creation, and information diffusion", Journal of Informetrics, 3 (3): 180-190. doi: 10.1016/j.joi.2009.03.007

Laudel, Grit (2002). "What do we measure by co-authorships?", Research Evaluation, 11 (1): 3-15. doi: 10.3152/147154402781776961

Lee, Sooho and Bozeman, Barry (2005). "The Impact of Research Collaboration on Scientific Productivity", Social Studies of Science, 35 (5): 673-702. doi: $10.1177 / 0306312705052359$

Letina, Srebrenka (2014). Analiza mreža suradnje znanstvenika iz tri polja društvenih znanosti od 1992. do 2012. [Network analysis of scientific collaboration in the three fields of social science from 1992 to 2012]. Doctoral dissertation. Zagreb: University of Zagreb.

Letina, Srebrenka (2016). "Network and actor attribute effects on the performance of researchers in two fields of social science in a small peripheral community", Journal of Informetrics, 10 (2): 571-595. doi: 10.1016/j.joi.2016.03.007

Lewis, Jenny M. (2013). Academic Governance: Disciplines and Policy. New York: Routledge.

Lewis, Jenny M., Ross, Sandy and Holden, Thomas (2012). "The how and why of academic collaboration: Disciplinary differences and policy implications", Higher Education, 64 (5): 693-708. doi: 10.1007/s10734-012-9521-8

Lotka, Alfred, J. (1926). "The frequency distribution of scientific productivity", Journal of the Washington Academy of Sciences, 16 (12): 317-324.

Mali, Franc, Kronegger, Luka, Doreian, Patrick and Ferligoj, Anuška (2012). "Dynamic scientific co-authorship networks", in: Andrea Scharnhorst, Katy Börner and Peter van den Besselaar (eds). Models of Science Dynamics: Encounters Between Complexity Theory and Information Sciences. Berlin: Springer, pp. 195-232. doi: 10.1007/978-3-642-23068-4

Meadows, Arthur Jack (1997). Communicating Research. London: Academic Press.

Melin, Göran and Persson, Olle (1996). "Studying research collaboration using co-authorships", Scientometrics, 36 (3): 363-377. doi: 10.1007/BF02129600

Melkers, Julia and Kiopa, Agrita (2010). "The social capital of global ties in science: The added value of international collaboration", Review of Policy Research, 27 (4): 389-414. doi: 10.1111/j.1541-1338.2010.00448.x

Merton, Robert K. (1968). “The Matthew Effect in Science”, Science, 159 (3810): 56-63. doi: 10.1126/science.159.3810.56

Moody, James (2004). "The structure of a social science collaboration network: Disciplinary cohesion from 1963 to 1999”, American Sociological Review, 69 (2): 213-238. doi: 10.1177/000312240406900204

Newman, Mark E. J. (2001). "The structure of scientific collaboration networks", Proceedings of the National Academy of Sciences, 98 (2): 404-409. doi: 10.1073/pnas.98.2.404 
Newman, Mark E. J. (2004). "Coauthorship networks and patterns of scientific collaboration", Proceedings of the National Academy of Sciences, 101: 52005205. doi: 10.1073/pnas.0307545100

Perc, Matjaž (2010). "Growth and structure of Slovenia's scientific collaboration network", Journal of Informetrics, 4 (4): 475-482. doi: 10.1016/j.joi.2010.04.003

Robins, Garry and Lusher, Dean (2013). "Illustrations: simulation, estimation and goodness of fit", in: Dean Lusher, Johan Koskinen and Garry Robins (eds). Exponential Random Graph Models for Social Networks: Theory, Methods, and Applications. Cambridge: Cambridge University Press, pp. 167-186. doi: 10.1017/CBO9780511894701

Robins, Garry, Pattison, Philippa and Elliott, Peter (2001). "Network models for social influence processes", Psychometrika, 66 (2): 161-189. doi: 10.1007/ BF02294834

Rodriguez Medina, Leandro (2014). Centers and Peripheries in Knowledge Production. New York: Routlege.

Schott, Thomas (1998). "Ties between center and periphery in the scientific worldsystem: Accumulation of rewards, dominance and self-reliance in the center", Journal of World-Systems Research. 4 (2): 112-144. doi: 10.5195/jwsr.1998.148

Schott, Thomas, Kugel, Samuel, Berrios, Ruben and Rodriguez, Keri L. (1998). "Peripheries in world science: Latin America and Eastern Europe", in: Thomas Cushman, Mike-Frank Epitropoulos and Victor Roudometof (eds). American Culture in Europe. Interdisciplinary Perspectives. Westport: Praeger, pp. 181204.

Snijders, Tom (2011). "Network dynamics", in: John Scott and Peter J. Carrington (eds). The SAGE Handbook of Social Network Analysis. London: SAGE, pp. 501-513.

Sonnenwald, Diane H. (2007). "Scientific collaboration", Annual Review of Information Science and Technology, 41 (1): 643-681. doi: 10.1002/aris.2007.1440410121

Toomela, Aaro (2007). "Sometimes One is More Than Two: When Collaboration Inhibits Knowledge Construction", Integrative Psychological and Behavioral Science, 41 (2): 198-207. doi: 10.1007/s12124-007-9015-x

Valente, Thomas W. (1995). Network models of the diffusion of innovations. Cresskill: Hampton Press.

Van Rijnsoever, Frank J. and Hessels, Laurens K. (2011). "Factors associated with disciplinary and interdisciplinary research collaboration", Research Policy, 40 (3): 463-472. doi: 10.1016/j.respol.2010.11.001

Vessuri, Hebe (1997). "Bitter Harvest. The growth of scientific community in Argentina", in: Jacques Gaillard, V. V. Krishna and Roland Waast (eds). Scientific Communities in the Developing World. New Delhi: SAGE, pp, 307-335.

Wagner, Catherine S. (2008). New Invisible College: Science for Development. Washington: Brookings Institution Press.

Wang, Peng, Robins, Garry, Pattison, Philippa and Koskinen, Johan (2014). MPNet: Program for the Simulation and Estimation of ( $\left.p^{*}\right)$ Exponential Random Graph Models for Multilevel Networks. User Manual. Melbourne: The University of Melbourne. 
Watts, Duncan J., Strogatz, Steven H. (1998). "Collective dynamics of 'smallworld' networks", Nature, 393: 440-442. doi: 10.1038/30918

Woolley, Richard, Sánchez Barrioluengo, Mabel and Turpin, Tim (2012). "Motivations for disciplinary and interdisciplinary collaboration among Australian social scientists", Annual Meeting of the Society for Social Studies of Science (4S). http://textlab.io/doc/17635434/among-australian-social.pdf.

Wuchty, Stefan, Jones, Benjamin F. and Uzzi, Brian (2007). "The increasing dominance of teams in production of knowledge", Science 316 (5827): 1036-1038. doi: 10.1126/science.1136099

Ynalvez, Marcus Antonius and Shrum, Wesley M. (2011). "Professional networks, scientific collaboration, and publication productivity in resource-constrained research institutions in a developing country", Research Policy, 40 (2): 204 216. doi: 10.1016/j.respol.2010.10.004

\section{Dosezanje izvan male znanstvene zajednice: modeli društvenog utjecaja na suradnju preko nacionalnih i disciplinarnih granica kod znanstvenika iz triju polja društvenih znanosti}

\section{Srebrenka LETINA}

Institut za društvena istraživanja u Zagrebu, Hrvatska

srebrenka@idi.hr (autorica zadužena za korespondenciju)

\section{Garry ROBINS}

Melbournška škola psihologijskih znanosti, Sveučilište u Melbourneu, Australija garrylr@unimelb.edu.au

Darja MASLIĆ SERŠIĆ

Odsjek za psihologiju, Filozofski fakultet, Sveučilište u Zagrebu, Hrvatska darja.maslic@ffzg.hr

Suradnja sa znanstvenicima iz drugih područja znanosti ili drugih zemalja važna je općenito za napredak znanosti, osobito za znanstvenike koji djeluju u malim i perifernim znanstvenim zajednicama. Cilj je ovog istraživanja bio ispitati postoje li mrežni (strukturni) efekti na vjerojatnost da će pojedini znanstvenik ostvariti koautorstvo/suradnju izvan svoje nacionalne i disciplinarne zajednice. Na temelju podataka o koautorstvu na publikacijama indeksiranim u dvjema međunarodnim bazama (Web of Science i Scopus) i jednoj nacionalnoj bazi (Nacionalna i sveučilišna knjižnica) konstruirana je mreža koautorstva za tri područja društvenih znanosti u Hrvatskoj. Testirana su tri strukturna prediktora (aktivnost, zaraza i popularnost (Ego-2Star/), a korištenje autologističkih modela atributa aktera omogućilo je istovremeno kontroliranje šest atributa aktera. Rezultati su potvrdili hipotezu o postojanju pozitivnog učinka zaraze (vjerojatnost suradnje sa znan- 
stvenicima izvan nacionalne i disciplinarne mreže veća je ako neposredni alter u mreži također ima vanjske suradnje) i negativnog učinka aktivnosti (oni koji surađuju s jednim ili više znanstvenika izvan svoje mreže, manje surađuju unutar svoje mreže) u mreži obrazovnih znanosti. Međutim, u mreži sociologa utvrđen je samo efekt negativne aktivnosti, dok u mreži psihologa nijedan strukturni efekt nije bio značajan prediktor suradnje izvan uže zajednice. Pronađen je značajan efekt broja radova napisanih u koautorstvu, ali ne i broja jednoautorskih radova, te dobi u svim trima poljima. Spol, lokacija i maksimalna snaga veze imali su različitu ulogu u trima istraživanim poljima. U radu su naglašeni metodološki aspekti analize mreža koautorstva i predlažu smjernice za buduća istraživanja.

Ključne riječi: autologistički modeli atributa aktera (ALAAM), mreža koautorstva, znanstvena suradnja, nacionalna i disciplinarna zajednica, periferna znanstvena zajednica, društvene znanosti 